\title{
Brand Image on Intention of Banking Services Using: The Case of Vietnam Banks
}

\author{
Do Hoai Linh ${ }^{1, *}$, Hoang Hai Yen², Nguyen Thi Hong Nhung ${ }^{2}$, Le Thanh Tam ${ }^{1}$ \\ ${ }^{1}$ Banking Department, School of Banking and Finance, National Economics University, Hanoi Capital, Vietnam \\ ${ }^{2}$ Commercial Banking Department, School of Banking, University of Economics of Ho Chi Minh City, Ho Chi Minh City, Vietnam
}

\section{Email address:}

linhdh@neu.edu.vn (D. H. Linh), linhdo.neu@gmail.com (D. H. Linh)

${ }^{*}$ Corresponding author

\section{To cite this article:}

Do Hoai Linh, Hoang Hai Yen, Nguyen Thi Hong Nhung, Le Thanh Tam. Brand Image on Intention of Banking Services Using: The Case of Vietnam Banks. International Journal of Sustainability Management and Information Technologies. Vol. 3, No. 6, 2017, pp. 63-72. doi: $10.11648 /$ j.ijsmit.20170306.12

Received: November 4, 2017; Accepted: November 27, 2017; Published: January 11, 2018

\begin{abstract}
The paper is aimed at estimating the impact of banking brand-image on the intention of customers and noncustomers to use banking services. The research is based upon questionnaires data from 362 random customers and noncustomers of nine banks in Vietnam, during the period from May to July of 2017, as well as SPSS 20 and AMOS were used to analyse the data and tested the estimation model, theories and hypotheses. The results show that for customers - the bank's reputation and brand attitude influence the intention banking services using; for non-customers - both brand image and brand attitude impact on the intention of the use of the bank's services. Recommendations are proposed to enhance brand image of banks for the final target of increasing banking services using.
\end{abstract}

Keywords: Brand Image, Corporate Image, Bank Image, Brand Associations, Brand Attitude, Brand Trust, Intention to Use

\section{Introduction}

With strong branding, banks can attract customers and create customers' trust and loyalty to the bank. It also enhances the effectiveness of promotional campaigns of competitors, hence; brand equity is an asset to create a difference and increases the chances of success for the bank. Identification and measuring the components of brand equity based on consumer behaviors have been studied by researchers since early 1990s, famous researchers are Aaker and Keller (Aaker, 1996; Keller, 1993.1998). The success of a brand depends on the level of value that customers perceived. Vietnamese commercial banks have recently become more interested in building and developing their brands. Bank brand equity has increasingly become an important factor in a number of banking performances. This research mainly focused on the impact of brand image and brand attitude on existing customers and potential customers. Moreover, the results provide some implications for the bank managers in the allocation of resources for building and developing the bank brand in order to maintaining and expanding customer network, increasing the bank revenues and profits.

\section{Literature Review and Hypotheses}

\subsection{An Overview of Brand Image}

\subsubsection{Brand Image}

Brand image is the linkage between the perceptions reflected as existing brand associations in the consumer's mind and brand, said by Keller (Keller, 1993, 1998; Lassa et al., 1995). In other words, Patterson (1999) stated that "brand image is perceptions of consumers about the brand attributes and associations, from which those consumers derive symbolic value". According to Keller (1993, 1998), brand image creates from perceptions of consumers about the brand associations, such as strength, uniqueness, favourability ... of a brand. Therefore, brand image occurs when the consumers hold some positive brand associations in memory and favourable response, in turn, can lead to enhance revenues, lower costs and greater benefits for the company. Such Keller's conceptualisation is shared by numerous scholars 
and brand image is considered one of major influencing factors in a number of conceptual models of customer-based brand equity (CBBE) (Dowling, 1988; Lassar et al., 1995; de Ruyter et al, 2000; Kazoleas et al., 2001; Hatch et al., 2003; Konecnik et al, 2006; Lin, 2008; Wu et al, 2009; Bravo, 2009; Pinar et al, 2010, 2012; Ghantous et al, 2013

\subsubsection{Corporate Image and Bank Image}

Although there are several definitions and different perspectives on corporate image, corporate image is usually understood "the image an audience has of an organization through the accumulation of received messages" (Fombrun, 1996). This concept is associated with the global brand equity's components of Keller (1993) and also supported by other scholars. According to Kazoleas et al (2001), Hatch et al (2003), Lemmink et al. (2003), Souiden et al. (2006), Bravo et al (2009), France et al (2015), Johnson et al (2015), de Leaniz et al (2016), corporate image is the result of a communication process in which the firm creates and transmits an identity that reflects the values and essence of the brand. Moreover, company cannot act directly on their corporate image, but they are able to change their associations by communicating with customers in an attractive and unique identity (Karaosmanoglu et al, 2006). Thus, corporate image can be interpreted in a way that the company has to communicate with customers using its identity.

Banks have different characteristics compared to other commercial or trading companies because banks are financial intermediaries. Bank performance depends on trust and credibility of its customers. Its brand is different from brands of other companies providing non-bank products or services. Its brand image focuses on the overall assessment of customers to the bank, rather than an assessment of one or several products and services. The overall brand image is contributed by many factors related to the bank's structure and operations, reputation and personnel, building and developing its brand.

According to Hardwick (1997), the weakness of financial brands mainly stems from the high intangibility of the services they provide. It is the fact that consumers decide to purchase products not only depending on the product quality, but also the services and intangible benefits added to these products. The relevance of branding increases with offer's intangibility (Brady et al., 2005). Since, the value of brand image is difficult to assess and its influence on customer behavior, especially customer's intention to choose the bank to deal with needs to study thoroughly.

Recently, the bank's services are fairly common, standardized and most of the banks have the ability to imitate products and services of each other. Therefore, the brand plays an important role in attracting customers to the bank. The bank has to build its different, unique brand and place its brand positioning in the minds of consumers. Besides, O'Loughlin (2005) found that the bank has to face a lot of difficulties in highly competitive markets and the product and service characteristics that can be easily imitated in many cases. Strong corporate associations can positively affect customers' perception about the brand differentiation (Chen, 2006). The difference is the central element in building a brand. Strong brand image is the different, unique brand, reflected in mind and the perception of the customer.

The experimental studies on bank image shows that the elements created visual impression of bank image are different and change over time due to changing in banking technology and services. Grönroos (1998) suggested that the reputation and credibility are the two main components measured the bank image. Pina (2009) identifies the six components constituting the bank image, including services offered, service accessibility, global impression, corporate social responsibility, location and personnel.

Most of studies on bank image analyzed the variables related to the types of services provided by the bank, service accessibility, branch appearance, personnel and the bank's reputation (Heerden, 1995; LeBlanc, 1996).

\subsubsection{Brand Attitude}

Brand attitude is the favourable or unfavourable trend of consumer against a certain brand (Fishbein, 1980) and the overall assessment of consumers on the brand. In general, the more favourable the attitude toward the behaviour, the stronger will be an individual's intention to perform the behaviour (Ajzen, 1991). Brand attitude assessment is based on the outstanding benefits which are perceived by customer and then formed a common attitude toward the brand. That is also the result of overall assessment of MacKenzie (1992), reflecting the attitude of consumers towards the brand. A positive attitude of customer towards a brand can increase the chance of using that brand. However, service offerings are often associated with higher perceived risk than manufactured goods (Mitchell, 1993; Murray, 1990). This is mainly due to services' characteristics such as their physical and mental intangibility (Laroche et al, 2004), as well as the associated heterogeneity that makes it harder to maintain a steady level of service quality (Ghantous et al, 2013).

Brand trust is related to brand attitude or it is a higher level of attitude, acts as a major antecedent of customers' commitment toward a brand. Brand trust plays an important role in building long-term relationships between consumers and their goods/services providers in the presence of high perceived risk (Fischer et al., 2004; Sichtmann, 2007) or maintaining service relationships with one's bank (Lewis, 2006; Ndubisi et al., 2007).

\subsubsection{Intention to Use}

Understanding the formation of consumer attitudes is necessary when applying the theory "attitude" in the research on the brand. Ajzen (1991) in TPB (Theory of Planned Behavior) proposed adding "perceived behavioural control" to the analysis of how attitude and behaviour are formed. Perceived behavioural control refers to "the perceived ease or difficulty of performing the behaviour" (Ajzen, 1991). In TPB, behavioural intention is central to the model and represents the extent of the individual's intentions to perform or not to perform one certain behaviour. Perceived 
behavioural control, together with behavioural intention, can be used to directly predict actual behaviour. Behavioural intention is an important mediator in the relationship between behaviour and other factors, such attitude, subjective norm and perceived behavioural control. In general, the more favourable the attitude toward the behaviour, the stronger will be an individual's intention to perform the behaviour. Based on TPB of Ajzen et al (1975, 1980), Tsai (2012) made further research on the factors that influence the intention to use products and services. The finding of the research indicated that: (i) brand and brand trust have significant positive impact on the intention to use the products and services; (ii) customer's perception about the benefits of services has significant positive impact on the intention to use products and services; (iii) consumers' attitudes positively influence intent to use the products and services.

\subsection{Research Hypotheses}

This research purposes to estimate the effects of banking brand image on intention of customers and non-customers to use a bank's services, in order to interpret:

(1) The influence of bank image on intention to use the bank's services

(2) The influence of brand attitude on intention to use the bank's services

Brand associations make up bank image are different from other corporate image due to its currency trading. This study is based on brand associations of bank image introduced by Pina (Pina et al., 2009).; including services offered, service accessibility, global impression, corporate social responsibility, location and personnel. Corporate social responsibility is an important attribute, makes the bank image became friendly and more humanities in customer's view. However, the pilot survey results of this research showed that Vietnamese commercial banks have not clearly expressed "social responsibility" in their bank images or have done social responsibility but their advertising is not enough to impress customers. Therefore, the customers could not answer the questions related to the banks' social responsibility. The researchers had to exclude this attribute from the brand image's components in this study.

Therefore, the following hypothesis will be explored:

H1. The more positive the bank image, the more intention to use bank's services. In with:

H1.1. Services offered have a positive impact on intention to use the bank's services of customers and non-customer.

H1.2. Service accessibility has a positive impact on intention to use the bank's services of customers and noncustomer.

H1.3. Global impression has a positive impact on intention to use the bank's services of customers and non-customer.

H1.4. Branch location has a positive on impact on intention to use the bank's services of customers and noncustomer.

H1.5. Personnel has a positive impact on intention to use the bank's services of customers and non-customer.

Brand image is an essential factor for understanding brand attitude, as the credibility of the new product increases when brand perceptions become more favourable (de Ruyter, 2000). Martínez (2010) showed that the more positive initial brand image, the more favourable attitude to the brand. The brand image has a positive influence on the motive and attitude of a consumer when the customer takes part in an important role in the decision-making process of consumption behaviour (Lin, 2008). On the other hand, brand image is also expressed in the customer's emotion of the brand. Brand emotion is an essential factor to clarify the brand image, as the reliability of a new product increases when customers have good emotion about the brand (Ruyter, 2000).

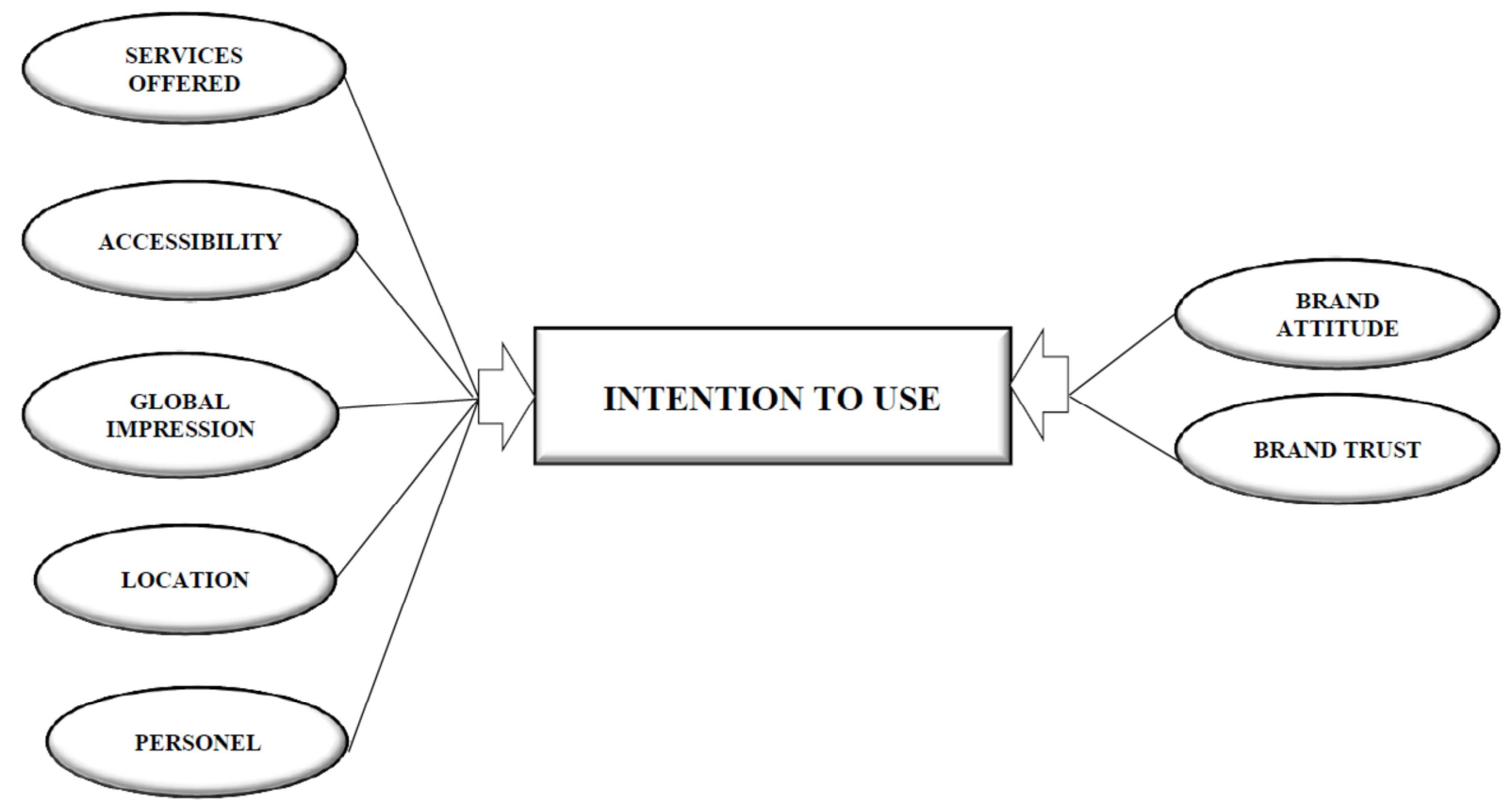

Figure 1. Research model. 
In the banking sector, brand emotion, brand awareness, customer satisfaction with the commercial banks will affect the intention to use the bank's services, increase word-of-mouth marketing or arising level of customer's loyalty (Bloemers et al., 1999). Moreover, according to Delgado-Ballester (2004), brand emotion has 2 components: cognitive component and emotional component. Cognitive ability of customers is their trust to the brand and customers' emotion is the attitude of customers towards the brand. This study considers the impact of these two components to the intention to use the bank's services of customers and non-customer. Building on this, the following hypotheses were introduced:

$\mathrm{H} 2$ : Brand emotion has a positive impact on the intention to use the bank's services of customers and non-customer. In with:

$\mathrm{H} 2.1$. Brand trust has a positive impact on the intention to use the bank's services.

$\mathrm{H} 2$.2. Brand attitude has a positive impact on the intention to use the bank's services.

The research model is proposed as in figure 1

\section{Methodology}

The qualitative and quantitative approaches with statistics analysis, empirical framework were combined in this research. The below diagram briefly explained how the research process was conducted:

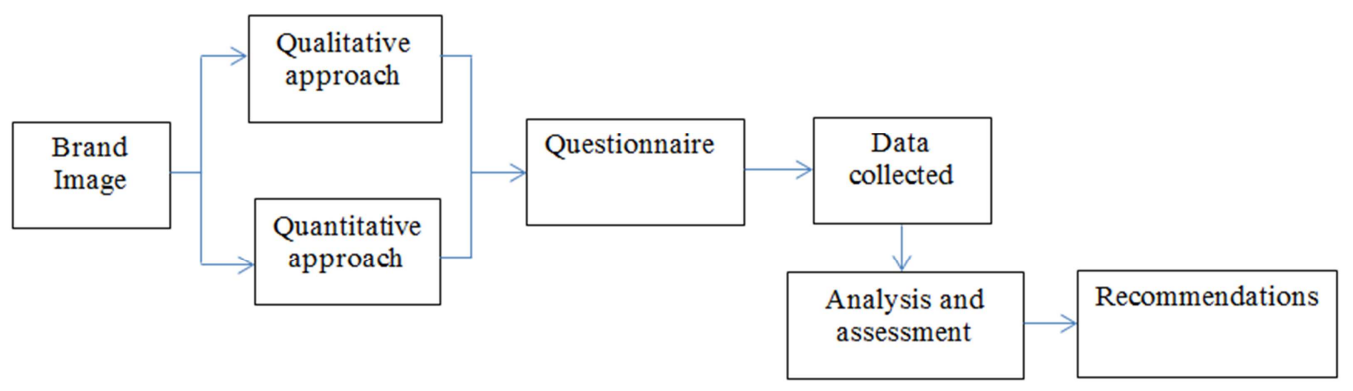

Source: Compilation by authors.

Figure 2. Research framework.

\subsection{Data Description}

The questionnaires were answered by 362 customers and noncustomers of nine commercial banks in Ho Chi Minh City from May to July of 2017, included three Vietnamese Stateowned banks, three Vietnamese joint stock commercial banks and three foreign banks in Vietnam. Among respondents, 233 customers had used the services of selected banks (existing customers) and 129 are not customers of these banks (potential customers). The banking group is selected according to criteria that are similar in the bank's size, operations, and target customers based on Vietnam Banking Report 2016. The respondents had the ages of 22-65 because at these ages they have more chances to use banking services or have their owned judgment about banking services.

\subsection{Methodology}

An empirical study with a consumer sample assessing nine commercial banks was the instrument to contrast our hypotheses, after conducting a pre-test with undergraduates.

A pilot interview was performed to assess how well the survey instrument captures the constructs it was supposed to measure and to test the validity and reliability of the instrument. Official survey was performed with data sets of 233 existing customers and 129 potential customers. All the 362 filled questionnaires are collected at the site in from May to July of 2017. SPSS 20 was used to analyze the data and test the estimation model, theories and hypotheses. Cronbach's alpha was used to verify the validity and reliability. For scale reliability and validity, internal consistency measures (i.e. Cronbach's alpha and average variance extracted [AVE]), convergent validity and discriminant validity were tested.

Research was carried out with 03 concepts: bank image, brand emotion, intention to use the bank's services. In which, bank image is measured by 5 components: services offered, service accessibility, global impression, corporate social responsibility, location and personnel. Brand emotion is measured by 2 components: brand trust and brand attitude. The scale used to measure the concepts and conceptual elements inherited from previous studies.

Table 1. Observing variables of concepts and conceptual elements.

\begin{tabular}{ll}
\hline Code & Items \\
\hline Cervices offered & \\
CC2 & Offering an ample variety of services \\
CC3 & Low loan's interest rate \\
CC4 & Offering personalized services to each customer \\
CC5 & Low services' commissions \\
Accessibility & Customers can get high interest rate of saving \\
KN1 & The services that offered by bank A are easy to use \\
KN2 & I can make operation with bank A though telephone. \\
KN3 & I can make operation with bank A though internet \\
KN4 & Bank A carries out operations quickly \\
KN5 & Bank A has a long historian \\
Reputation & \\
UT1 & Bank A has a good reputation \\
UT2 & Avoid violation of business and ethical issue. \\
UT3 & Bank A keeps high commitment to customers. \\
UT4 & A has a good image \\
Branches & \\
ML1 & A has a lot of branches in compare to other banks \\
ML2 & The A's branch is close to my home/ my place \\
\hline
\end{tabular}


Table 1. Continued.

\begin{tabular}{ll}
\hline Code & Items \\
\hline Human resource & \\
NS1 & Quick services offer \\
NS2 & Friendly and warm \\
NS3 & Professional \\
NS4 & Pay attention on customers' benefit \\
Believe on brand & \\
TT1 & A's services are fit with my expectations. \\
TT2 & A make a sense of confidence to me \\
TT3 & I believe that customers will satisfy with A \\
TT4 & A is honest bank \\
TT5 & A will refund to the customers if it has any mistake. \\
Attitude of brand & \\
TĐ1 & I feel believe with A 'services. \\
TĐ2 & I feel happy when I make transaction with A \\
TĐ3 & I feel relax whenever I have transaction with A \\
Intention to use & \\
YDINH1 & I may reuse A' services \\
YDINH2 & I am sure I will use A 'service whenever I need bank's \\
YDINH3 & service \\
\hline
\end{tabular}

Source: Primary data.

\section{Results and Discussions}

\subsection{Findings from Customer Survey}

Alpha reliability coefficients were calculated for the identified factors. According to Cronbach [38] and Hair [39], Cronbach's alpha values $>0.07$ is acceptable and deemed to be adequate. AVE values $>0.50$ are considered to be adequate. Discriminant validity is established when the estimated correlation between the factors is $<0.85$.

The samples of 233 valid questionnaires for existing customers were analyzed to measure the reliability of Cronbach's alpha. The results of Cronbach Alpha helped to eliminate variables, including CC3, NS3, UT2 and KN5. Other 33 variables are acceptable and considered to be adequate. The outputs of EFA with Promax rotation, forcing 8 factors produce $72.57 \%$ total variance extracted and the eigenvalue of.765. In other words, the 5 factor measuring "brand image", intention to use, and the 2 measuring "brand emotion" represent $72.57 \%$ the variables measuring them.

Table 2. Cronbach Alpha of customer's data

\begin{tabular}{|c|c|c|c|c|}
\hline Item & Scale Mean if Item Deleted & Scale Variance if Item Deleted & Corrected Item-Total Correlation & Cronbach's Alpha if Item Deleted \\
\hline \multicolumn{5}{|c|}{ Services offered: Cronbach alpha $=.633$} \\
\hline $\mathrm{CC} 1$ & 12.5108 & 6.590 & .363 & .591 \\
\hline CC5 & 12.4589 & 6.397 & .474 & .541 \\
\hline $\mathrm{CC} 3$ & 13.0952 & 6.808 & .275 & .636 \\
\hline $\mathrm{CC} 4$ & 13.2294 & 6.108 & .385 & .582 \\
\hline $\mathrm{CC} 2$ & 13.3983 & 6.345 & .458 & .546 \\
\hline \multicolumn{5}{|c|}{ Accessibility: Cronbach alpha $=.672$} \\
\hline KN1 & 15.2368 & 8.137 & .633 & .526 \\
\hline KN2 & 15.4254 & 8.184 & .497 & .586 \\
\hline KN3 & 15.0439 & 8.210 & .585 & .546 \\
\hline KN4 & 15.4781 & 9.581 & .363 & .648 \\
\hline KN5 & 15.1140 & 11.124 & .108 & .749 \\
\hline \multicolumn{5}{|c|}{ Reputation: Cronbach alpha $=.450$} \\
\hline UT1 & 9.7167 & 4.109 & .340 & .299 \\
\hline UT2 & 10.9700 & 5.210 & -.075 & .748 \\
\hline UT3 & 10.0172 & 4.138 & .415 & 245 \\
\hline UT5 & 10.0858 & 3.596 & .542 & .098 \\
\hline \multicolumn{5}{|c|}{ Human resource: Cronbach alpha $=.608$} \\
\hline NS1 & 10.5603 & 10.040 & .455 & .510 \\
\hline NS2 & 10.4310 & 9.337 & .614 & .421 \\
\hline NS3 & 10.3147 & 6.407 & .294 & .778 \\
\hline NS4 & 10.6293 & 10.762 & .478 & .523 \\
\hline \multicolumn{5}{|c|}{ Believe on brand: Cronbach alpha $=.827$} \\
\hline STT1 & 14.2554 & 7.800 & 646 & .785 \\
\hline STT2 & 14.0909 & 7.448 & .742 & .757 \\
\hline STT3 & 14.0779 & 7.785 & .683 & .775 \\
\hline STT5 & 14.0952 & 8.113 & .633 & .790 \\
\hline STT8 & 14.4762 & 8.677 & .430 & .848 \\
\hline \multicolumn{5}{|c|}{ Attitude on brand: Cronbach alpha $=.871$} \\
\hline TD1 & 6.9310 & 3.095 & .672 & .888 \\
\hline TD2 & 7.2500 & 2.639 & .789 & .785 \\
\hline TD3 & 7.2586 & 2.738 & .804 & .772 \\
\hline
\end{tabular}

Source: Primary data.

The results of EFA showed that the research concepts have changed compared to these concepts in the theoretical framework. The concept of "bank image" is adjusted to 6 components: service suitability, price, accessibility, reputation, location and personnel. 
Table 3. EFA of customers 'data.

\begin{tabular}{|c|c|c|c|c|c|c|c|c|}
\hline \multirow{2}{*}{ Items } & \multicolumn{8}{|c|}{ Factors } \\
\hline & 1 & 2 & 3 & 4 & 5 & 6 & 7 & 8 \\
\hline TD2 & .884 & & & & & & & \\
\hline STT8 & .823 & & & & & & & \\
\hline TD3 & .821 & & & & & & & \\
\hline STT1 & .782 & & & & & & & \\
\hline STT2 & .739 & & & & & & & \\
\hline STT3 & .718 & & & & & & & \\
\hline TD1 & .601 & & & & & & & \\
\hline STT5 & .578 & & & & & & & \\
\hline NS1 & & .915 & & & & & & \\
\hline NS2 & & .674 & & & & & & \\
\hline KN4 & & .511 & .475 & & & & & \\
\hline NS4 & & .451 & & & & & & \\
\hline KN2 & & & .860 & & & & & \\
\hline KN3 & & & .748 & & & & & \\
\hline KN1 & & & 601 & & & & & \\
\hline $\mathrm{CC} 1$ & & & & .937 & & & & \\
\hline CC5 & & & & .847 & & & & \\
\hline YDINH2 & & & & & .833 & & & \\
\hline YDINH3 & & & & & -.833 & & & \\
\hline YDINH1 & & & & & .825 & & & \\
\hline ML2 & & & & & & .892 & & \\
\hline ML1 & & & & & & .878 & & \\
\hline UT1 & & & & & & & .914 & \\
\hline UT5 & & & & & & & .620 & \\
\hline UT3 & & & & & & & .495 & \\
\hline $\mathrm{CC} 4$ & & & & & & & & .863 \\
\hline $\mathrm{CC} 2$ & & & & & & & & .730 \\
\hline
\end{tabular}

Source: Primary data.

On the other hand, according to the literature review, "brand emotion" has two elements: brand trust and brand attitude. After the data analyses "brand emotion" is unidirectional concept, measured by 8 observation variables. Results correlation regression showed that among 7 concepts and their elements, only "brand emotion" and "bank reputation" have significant impact on the intention to use the bank's services. The impact of brand emotion is at average level $($ Beta $=.369)$ and bank reputation impact is weak $($ Beta $=.138)$.

Regression of intension to use of existing customers:

$$
\text { Intention to use }=0.369 \text { Brand emotion }+0.138 \text { Bank reputation }
$$

As a result, if the brand emotion increases by 1 , intention to use the banking services would increase to 0.369 . If the bank reputation increases by 1 , intention to use would increase by 0.138 . The hypothesis $\mathrm{H} 1.4$ and $\mathrm{H} 2$ are accepted.

\subsection{Findings from Potential Customers}

The sample of 129 valid questionnaires for potential customers were analysed to measure the reliability of Cronbach's alpha. The test of reliability by Cronbach alpha removed the observing variable KN5, UT2, NS3 and YDINH3. The remaining observing variables for the concepts were analyzed for convergent validity, discriminant validity by exploratory factor analysis. Total variance extracted when forcing 8 factors with Equamax rotation is $71.03 \%$. The Eigen value was. 908 and KMO equals .854 .

Table 4. Cronabach Alpha of potential customers.

\begin{tabular}{lllll}
\hline Items & Scale Mean if Item Deleted & Scale Variance if Item Deleted & Corrected Item-Total Correlation & Cronbach's Alpha if Item Deleted \\
\hline \multicolumn{2}{l}{ Services offered: Cronbach Alpha $=.561$} & & & .526 \\
CC1 & 12.6170 & 6.110 & .284 & .426 \\
CC5 & 12.5745 & 5.623 & .479 & .551 \\
CC3 & 13.2234 & 6.089 & .242 & .485 \\
CC4 & 13.3404 & 5.109 & .358 & .531 \\
CC2 & 13.5638 & 6.120 & .274 & .526 \\
Accessibility: Cronbach Alpha $=.672$ & & & .586 \\
KN1 & 15.2368 & 8.137 & .633 & .546 \\
KN2 & 15.4254 & 8.184 & .497 & .648 \\
KN3 & 15.0439 & 8.210 & .585 & .749 \\
KN4 & 15.4781 & 9.581 & .363 & .108 \\
KN5 & 15.1140 & 11.124 & & \\
Reputation: Cronbach Alpha $=.450$ & & & \\
\hline
\end{tabular}




\begin{tabular}{lllll}
\hline Items & Scale Mean if Item Deleted & Scale Variance if Item Deleted & Corrected Item-Total Correlation & Cronbach's Alpha if Item Deleted \\
\hline UT1 & 9.7167 & 4.109 & .340 & .299 \\
UT2 & 10.9700 & 5.210 & -.075 & .748 \\
UT3 & 10.0172 & 4.138 & .415 & .245 \\
UT5 & 10.0858 & 3.596 & .542 & .098 \\
Human resource: Cronbach Alpha $=.608$ & & & .510 \\
NS1 & 10.5603 & 10.040 & .455 & .421 \\
NS2 & 10.4310 & 9.337 & .614 & .778 \\
NS3 & 10.3147 & 6.407 & .294 & .523 \\
NS4 & 10.6293 & 10.762 & .478 & .785 \\
Believe on brand: Cronbach Alpha $=.827$ & & & .757 \\
STT1 & 14.2554 & 7.800 & .646 & .775 \\
STT2 & 14.0909 & 7.448 & .742 & .790 \\
STT3 & 14.0779 & 7.785 & .683 & .848 \\
STT5 & 14.0952 & 8.113 & .633 & .888 \\
STT8 & 14.4762 & 8.677 & .430 & .785 \\
Attitude on brand: Cronbach Alpha $=.871$ & & & .772 \\
TD1 & 6.9310 & 3.095 & .672 & .350 \\
TD2 & 7.2500 & 2.639 & .789 & .208 \\
TD3 & 7.2586 & 2.738 & .804 & .864 \\
Intention to use: Cronbach Alpha $=.595$ & & & .505 & \\
YDINH1 & 6.0732 & 2.675 & .617 & .173 \\
YDINH2 & 6.1301 & 2.589 & & \\
YDINH3 & 7.3089 & 3.051 &
\end{tabular}

Source: Primary data.

While the samples of potential customers is concentrated samples, not diversification (customers at ages 20-30 accounted for $93 \%$ and $42.3 \%$ doing seasonal work), the hierarchical multiple regression was not conducted, multiple regression with the dependent variable is the "overall intention to use". The independent variable is the variable component of the bank image and brand emotion.

Table 5. EFA of potential customer.

\begin{tabular}{lllllllll}
\hline \multirow{2}{*}{ Items } & \multicolumn{2}{l}{ Factors } & & & & & & \\
\cline { 2 - 7 } & $\mathbf{1}$ & $\mathbf{2}$ & $\mathbf{3}$ & $\mathbf{4}$ & $\mathbf{5}$ & $\mathbf{6}$ & $\mathbf{7}$ & $\mathbf{8}$ \\
\hline STT5 & .750 & & & & & & & \\
STT1 & .735 & & & & & & & \\
STT2 & .622 & & & & & & & \\
NS4 & .572 & .447 & & & & & \\
STT3 & .512 & & & & & & \\
UT3 & & .809 & & & & & \\
UT5 & & .686 & & & & & \\
UT1 & & .624 & & & & & \\
NS2 & .563 & .577 & & & & & \\
NS1 & & & & & & & \\
TD2 & & & .791 & & & & \\
TD1 & & & .658 & & & & \\
TD3 & .542 & & .614 & & & & \\
KN3 & & & & .808 & & & \\
KN2 & & & & & .713 & & & \\
KN1 & & & & & & & \\
\hline
\end{tabular}

\begin{tabular}{|c|c|c|c|c|c|c|c|c|}
\hline \multirow{2}{*}{ Items } & \multicolumn{8}{|c|}{ Factors } \\
\hline & 1 & 2 & 3 & 4 & 5 & 6 & 7 & 8 \\
\hline KN4 & & & .427 & .475 & & & & \\
\hline STT8 & & .426 & & -.447 & & & & \\
\hline $\mathrm{CC} 5$ & & & & & .803 & & & \\
\hline $\mathrm{CC} 1$ & & & & & .745 & & & \\
\hline ML1 & & & & & & .825 & & \\
\hline ML2 & & & & & & .769 & & \\
\hline YDINH1 & & & & & & & .928 & \\
\hline YDINH2 & & & & & & & .923 & \\
\hline $\mathrm{CC} 3$ & & & & & & & & .809 \\
\hline $\mathrm{CC} 4$ & & & .414 & & & & & .727 \\
\hline $\mathrm{CC} 2$ & & & & & & & & .407 \\
\hline
\end{tabular}

Source: Primary data.

Multiple regression results show that there are 4 factors that directly impact on intention to use the bank's services of potential customers: bank trust, bank reputation, accessibility and price. Among them, brand trust has the highest impact on intend to use the bank's and services. On the other hand, other factors such as service offered, branch location, the product suitability have very little or no effect on intend to use the bank's and services of potential customers.

Regression of intension to use of potential customers:

Intention to use $=0.476$ Brand trust +0.264 Bank reputation +0.143 Services accessibility +0.148 Price

Accordingly, if the brand trust increases by 1 , intention to use the bank's services of potential customers would increase to 0.476 . If the bank reputation increases by 1 , intention to use would increase by 0.264 .

The hypothesis H1.2, H1.4 and H2.1 are accepted. The new concept "Price" has been found and positive impacted on intention to use bank' services of potential customers.

\section{Research Implications}

The results show that existing customers have impression on the "brand image" and "brand attitude" based on their 
banking experiences. Nevertheless, only "brand attitude" really makes an impression, makes customers choose the bank's services in their next transactions. Consequently, banks should focus on creating a friendly, comfortable atmosphere across all communication channels when they communicate with customers. Moreover, bank should provide accurate, trustworthy information and honesty advertising to gain customer's trust. The processes and procedures at the banks should be simple, easy to understand and convenience so that customers feel confident when they deal with banks. Banks should also pay attention to the existing customers' satisfaction and feedback, in order to maintain their positive brand attitude. Research results also show that professional services, friendly staffs have play important role in creating good impression on brand image in customer's mind and their intention to use bank's services. Meanwhile, other elements such as interest rates, commissions, location almost have no impression on existing customers.

Besides, the only element of "bank reputation" of the "bank image" has positive impact on the intention to use bank's services of existing customers. This finding is important given the current Vietnamese banking context as an emerging industry. With the progressive liberalization of the Vietnamese economy, the establishment of new national and foreign banks in Vietnam will probably accelerate and further develop. The foreign banks have advantage about their public status and long presence on the market, benefit from a positive image and are perceived by customers as presenting little risk. New established Vietnamese commercial banks will suffer in this context from a reputation deficit when competing with foreign banks. The lack of reputation could result in higher information asymmetry since the customers have little knowledge about the new banks. This context and our findings have implications for the newly established banks. They should not pursue the dominant marketing approach on the Vietnamese market by focusing on short-term customer benefits and overusing promotional techniques. Instead, they should establish a unique and strong corporate image focused on the bank's integrity, credibility and humanities to enhance their bank's reputation.

For potential customers, "brand trust" has strong impact on intention to use bank's services at higher level than existing customers. Brand trust of potential customers usually acquire mainly through advertising from the banks which is considered to be sincere, honest and will meet customer's expectations rather than focusing on making profits for the banks.. On the other hand, "bank reputation" also impacts on the intention to use bank's services of potential customers. This finding implicates that "bank reputation" is a precious asset of all banks. The study results are also consistent with the fact that when potential customers have not got any bank experience with the new bank, the bank is only known through advertising. If the bank has good reputation in the market, potential customers will trust it when they have to make the decision to use the bank's services. In addition, potential customers are also interested in the ability to access services and pricing when choosing a bank to get banking services, while existing customers are no longer interested in these factors. However, the element "price" impacts on intention to use bank's services of potential customers, but not as strong as the effect of "brand trust" and "bank reputation". Hence, banks should build their integrity, credibility and humanities to enhance their bank's reputation and customers' trust, rather than focus on "price" benefits and overuse promotional techniques.

\section{Conclusion}

The research set out to investigate the influence of brand image on intention to use the bank's services of existing and potential customers in banking sector in Vietnam. The hypotheses developed based on previous research mainly in western economies are predominately corroborated by the quantitative survey. The research measures impact of two elements of brand image and brand emotion on intention to use, using adjusted composition measurement scales, analyze the reliability, convergent validity and standardized factor loadings. The composition measurement scales can be used for further research.

The findings indicate that: (1) For customer, only the bank reputation (one of the components of the bank image) and brand attitude have influence on the intention to use the bank's services; (2) For non-customers, both brand image and brand attitude have influence on the intention to use the bank's services. There are several elements of brand image have impact on the intention to use of non- customers, such as brand trust, bank reputation, service accessibility and price. "Price" is a new element discovered during the data analysis process.

\section{Limitations and Future Study}

Brand image includes the element of the "social responsibility" of the bank. However, the authors have encountered problems upon collecting information related to the customer's comment about social responsibility of the bank. Customers were unable to answer the question regarding to social responsibility of the bank due to lack of this information. Further research can perform qualitative research through deep interviews or group discussion to know more about the customer's perception of the banks' social responsibility and its impact on intention to use bank's services.

Moreover, the initial research designed to examine whether the intention to use bank's services of the customers and non-customers is different among three banking groups. However, the data processed by the stratification method and selected random sample, the sample size of each bank group is not large enough to use this method, especially for banking groups with $100 \%$ foreign capital. Further research may enlarge the scale or be done only for one group of customers (existing or potential customers) and tested the differences among three banking groups. 


\section{References}

[1] Aaker, D. A. (1996). Building Strong Brand. New York: Free Press.

[2] Aaker, D. A. \& Álvarez del Blanco, R. M. (1995). Estatura de la Marca: Medir el Valorpor Productos y Mercados. HarvardDeusto Business Review, 69, 74-87.

[3] Ajzen, I. (1991). The theory of planned behavior. Organizational Behavior and Human Decision Processes, 50, 197-211.

[4] Ajzen, I. \& Fishbein, M. (1980). Understanding attitudes \& predicting social behavior. New Jersey: Prentice Hall.

[5] Ambler, T. \& Styles, C. (1996). Brand development versus new product development: Towards a process model of extension. Marketing Intelligence \& Planning, 14 (7), 10-9.

[6] Assael, H. (2004), Consumer Behavior: A Strategic Approach, New York: Hounghton Mifflin.

[7] Bennett, P. D. (1995). Dictionary of Marketing Terms (2 $2^{\text {nd }}$ ed.). Chicago: McGraw-Hill.

[8] Bloemer, J., de Ruyter, K., \& Wetzels, M. (1999). Linking perceived service quality and service loyalty: a multidimensional perspective. European Journal of Marketing, 33 $(11 / 12), 1082-1106$.

[9] Brand Attitude. (n. d.) Farlex Financial Dictionary. (2009).

[10] Brady, Brian L. Bourdeau, Julia Heskel, (2005). The importance of brand cues in intangible service industries: an application to investment services. Journal of Services Marketing, 19 (6), 401-410.

[11] Brown, T. J. \& Dacin, P. A. (1997). The company and the product: corporate associations and consumer product responses. Journal of Marketing, 61, 68-84.

[12] Cornelius H. Van Heerden, Gustav Puth, (1995). Factors that determine the corporate image of South African banking institutions: an exploratory investigation. International Journal of Bank Marketing, 13 (3), 12-17.

[13] Cronbach, L. J. (1951). Coefficient alpha and the internal structure of test. Psychometrika, Vol. 16, No. 3, pp. 297-334.

[14] Delgado-Ballester, E. (2004). Applicability of a brand trust scale across product categories: a multigroup invariance analysis. European Journal of Marketing, 38, No. 5-6, 573592.

[15] Engel, J. E., Blackwell, R. D. and Miniard, P. W. (2006). Consumer Behavior $\left(10^{\text {th }}\right.$ ed.). South-Western: Thomson.

[16] Fishbein, M. \& Ajzen, I. (1975). Belief, attitude, intention, and behavior: An introduction to theory and research. MA: Addison-Wesley.

[17] Gamble, P. R., Stone, M., \& Woodcock, N. (2006). Up Close \& Personal?: Customer Relationship Marketing@ Work. London: Kogan Page.

[18] Gaston LeBlanc, Nha Nguyen, (1996). Cues used by customers evaluating corporate image in service firms: An empirical study in financial institutions. International Journal of Service Industry Management, 7 (2), 44-56.
[19] Gilmore, J. H., \& Pine II, B. J. (2007). Authenticity: What consumers really want $\left(1^{\text {st }}\right.$ ed.). USA: Harvard Business Review Press.

[20] Gro"nroos, C. (1988). Service quality: the six criteria of good perceived service quality. Review of Business, 9, No. 3 10-13.

[21] Guiltinan, J. P., Paul, G. W., \& Madden, T. J. (1997). Marketing management: strategies and programs ( $6^{\text {th }}$ ed.). London: McGraw-Hill.

[22] Hardwick, R. (1997). Brand dynamics in financial services. The International Broker, September, 11-15.

[23] Hair, J., Black, B., Babin, B., Anderson, R. and Tathan, R. (2006), Multivariate data analysis, 6th ed., Prentice Hall, New York.

[24] Howard, D. J. and Gengler, C. E. (2001). Emotional contagion effects on product attitudes. Journal of Consumer Research, $28,189-201$.

[25] Keller, K. L. (1993). Conceptualising, measuring and managing customer-based brand equity. Journal of Marketing, $57(1), 1-22$.

[26] Keller, K. L. (1998). Strategic Brand Management. NJ: Prentice Hall.

[27] Keller, K. L., \& Aaker, D. A. (1997). Managing the corporate brand: the effect of corporate marketing activity on consumer evaluations of brand extensions. Marketing Science Institute, 97-106.

[28] Ko de Ruyter \& Martin Wetzels (2000). The MarketingFinance Interface: A Relatio. nal Exchange Perspective. Journal of Business Research, 50 (2), 209-215.

[29] Lassar, W. \& Mittal, B, Sharma, A. (1995). Measuring customer-based brand equity. Journal of Consumer Marketing, 12 (4), 11-9.

[30] Lin, C.-W. and Song, J.-F. (2008). Consumer response of price-matching refund policies: effect of perceived credibility. NTU Management Review, 18 (2), 197-228.

[31] Nguyễn Đình Thọ \& Nguyễn Thị Mai Trang (2009). Nghiên cúu khoa hoc trong Quản trị Kinh doanh. TP. HCM: NXB Thống Kê.

[32] Pina, J. M. (2009). The role of bank image for customers versus non-customers. International Journal of Bank Marketing, 27 (4), 315-334.

[33] Pina, J. M., Iversen, N. M., \& Martinez, E. (2010). Feedback effects of brand extensions on the brand image of global brands: a comparison between Spain and Norway. Journal of Marketing Management, 26 (9-10), 943-966.

[34] Plummer, J. T. (1984). How personality makes a difference. Journal of Advertising Research, 23, 27-31.

[35] Syvia, J. K. \& Chan-Olmsted, S. M. (2005). Comparative effects of organization-public relationships and productrelated attributes on brand attitude. Journal of Marketing, 11 (3), 145-170.

[36] Voss, K. E., \& Spangenberg, E. R., Grohmann, B. (2003). Measuring the hedonic and utilitarian dimensions of consumer attitude. Journal of Marketing Research, 40 (3), 310-320.

[37] Teresa Montaner, José M. Pina, (2009). Extending the brand: controllable drivers of feedback effects. Journal of Product \& Brand Management, 18, 394-403. 
[38] Tsai W. (2012). A study of consumer behavioral intention to use e-books: the Technology Acceptance Model perspective. Innovative Marketing, 8 (4), 55-66.

[39] Vakratsas, D. and Ambler, T. (1999). How advertising works: what do we really know?. Journal of Marketing, 63, No. 1 2643.
[40] Vietnamnet - Top 10 most prestigious Vietnamese commercial banks in 2016, Vietnam Report (2016). Available from: < $\mathrm{http} / / /$ vietnamnet.vn/vn/kinh-doanh/tai-chinh/top-10-nganhang-thuong-mai-viet-nam-uy-tin-nhat-2016-314055.html>. 